
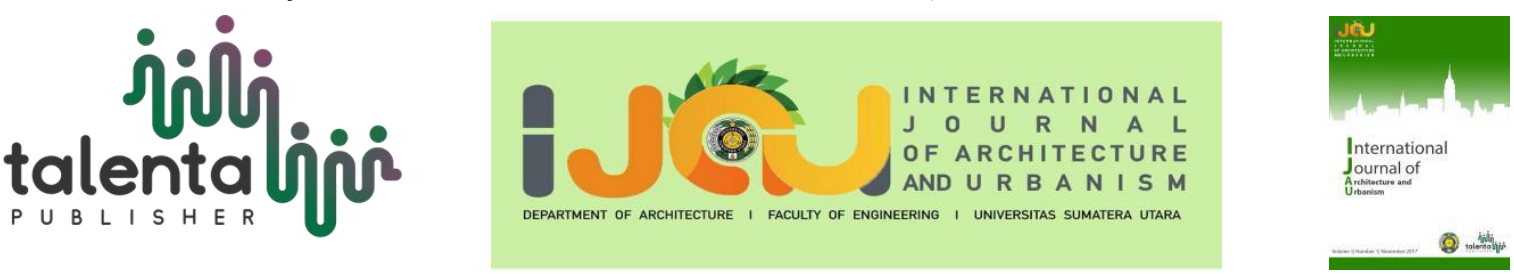

\title{
Design of Batak Toba Art and Culture Museum Center In The City of Medan By Applying Neovernacular Architecture Themes.
}

\author{
Julius Putra Simbolon ${ }^{1 *}$, Nelson Siahaan ${ }^{1}$ \\ ${ }^{1}$ Department of Architecture, Faculty of Engineering, Universitas Sumatera Utara, Medan, Indonesia
}

\begin{abstract}
Medan City is a city that has a variety of cultures and traditions. This diversity can give color to the world of tourism, especially in the city of Medan. One of the customs and cultures in the city of Medan is the Batak Toba, a native of the North Sumatera province. Tourism with high cultural value will make a positive impact on visitors who come to study and recreate in the tourism area, especially this museum. The design involves two different aspects where the design must be able to unite the Vernacular aspects that exist in the existing site as well as the modern touch of Neovernacular Architecture. The diversity of the arts and culture of Batak Toba Culture increasingly supports the achievement of space inside and outside the museum. It attracts visitors to calm the mind, relax, and learn many things about Batak Toba Arts and Culture. The existence of the Batak Toba Arts and Culture Museum is expected to increase the number of local and foreign tourists visiting the area to find out and perverse the Batak Toba culture.
\end{abstract}

Keyword: Medan, Museum, Batak, neo-vernacular architecture

Received 28May 2021|Revised15 August 2021 | Accepted 22 August 2021

\section{Introduction}

Indonesia is inhabited by various walks of life, groups, and ethnic groups. Culture itself is a characteristic of ethnic groups in Indonesia, and it cannot be denied either because of the many islands or because of the historical development of the various ethnic groups. With the diversity of ethnic groups in Indonesia, it turns out to be very potential to develop natural attractions, arts, crafts, and Culture of each tribe in Indonesia [1]. One Culture that can be used as tourism is the Batak tribe, especially Lake Toba tourism. Lake Toba itself is part of the 10 National Tourism Strategic Areas, prioritized for development by the Ministry of Tourism.

\footnotetext{
*Corresponding author at: Department of Architecture, Faculty of Engineering, University of North Sumatera, Perpustakaan Street, J07 Building, Medan, 20155, Indonesia.

E-mail address: juliussimbolon1@gmail.com
} 
Therefore, it is inevitable that Lake Toba can attract so many local and foreign tourists; this shows that many potentials can be developed in the tourism activity sector to advance the region itself in terms of social and economic aspects of the villagers.

However, the support in the tourism sector is only in the form of hotels, inns, or local resorts. It is sporadic to find a tourist area that aims to get to know the culture, art, and history of the Lake Toba region itself. The development of cultural tourism in the Lake Toba area in addition to hotels, lodging, and resorts currently include Sigale-Gale statues in Simanindo sub-district, Simalungun Museum in Pematang Siantar City, KMP Sinar Bangun Monument at Tigaras port, Raja Batak cemetery in Tomok, a traditional Batak village in Huta Sialagan, mystical tourism at the top of 'Pusuk Buhit', and many more. As a priority tourist attraction developed in Indonesia, the development of Lake Toba tourism should introduce more Culture, history, and local arts to tourists to make Lake Toba world-class tourism. Therefore, all parties can develop Lake Toba into a world-class tourism centre by adding areas or other tourism support to support introducing Culture around the area, such as the Toba Batak art and culture museum.

Introducing Toba Batak culture to local and foreign tourists is paramount to support the knowledge of Culture itself to the world. To simplify and increase the potential for tourist's interest, the Toba Batak arts and culture museum is located in Medan, where Medan is the capital of North Sumatra province which can represent the Toba Batak as one of the cultures in North Sumatra. Judging from the location that has been determined, the city of Medan has excellent potential to attract residents or tourists to learn more about the history, art, and Culture of the Toba Batak in an urban area where most residents are not Toba Bataks [2]. Potential cultural tourism attractions can be utilized as a priority for tourism development in urban areas without visiting Lake Toba. This museum makes the Toba Batak culture the basis for the design. The idea arose to develop it into a tourist attraction that offers cultural performances, handicrafts and represents the cultural history of the Toba Batak culture.

\section{Literature Review}

\section{Museum}

A museum collects artefacts and other objects of artistic, cultural, historical, or scientific importance. Many public museums make these items available for public viewing through exhibitions that may be permanent or temporary [3]. The largest museums are located in big cities throughout the world, while thousands of local museums exist in small cities, towns, and rural areas. The museum has a variety of purposes, from serving researchers and specialists to serving the general public. The aim of serving researchers is increasingly shifting to serving the general public [4].

A deeper and more international understanding was put forward by the International Council of Museums (ICOM), namely: The Museum is a permanent non-profit institution that serves the community and its development, is open to the public, whose task is to collect, preserve, 
research, communicate, communicate, and exhibit humanity's intangible and intangible heritage and its environment, for educational, research and entertainment purposes [5].

\section{Art and Culture}

In language, art is derived from Sanskrit 'Sani', which means offerings, worship, or service. From this understanding, it can be concluded that art has a very close relationship with various religious ceremonies of ancestors, which in turn is referred to as art. Art in the Dutch-Malay dictionary arrangement of Klinkert is interpreted as wisdom, knowledge, knowledge, intelligence, craftsmanship. This understanding is by the word art in English, which means 'skill' in making or doing written in Art and The Arts, The World Book Encyclopedia. Art, in this sense, refers more to actions or skills, not knowledge. Understanding of art refers to the act or skill that is in line with the origin of the word art in Greek, namely techne, which means skills [6]. In comparison, Culture comes from the Sanskrit language that is 'Buddhayah', which is the plural form of buddhi ('Budia' or reason), interpreted as matters relating to reason and human reason. Another form of the word a Culture is the culture that comes from the English language, culture, and Latin Culture [7].

\section{Batak Toba}

Toba Batak is one of the six sub-ethnic Batak tribes who generally reside in the residency of Tapanuli, and in 2008 the Tapanuli region was united in the Province of North Sumatra. Moreover, now the Batak tribe are silent in an area known as several districts, namely Toba Samosir Regency, Humbang Hasundutan Regency, Samosir Regency, North Tapanuli Regency, parts of Dairi Regency, Central Tapanuli Regency, Sibolga City, and surrounding areas. The Bataknese also know the ancient cooperation system in terms of farming. Toba Batak community knowledge in terms of gathering, such as herbs into traditional medicine, such as turmeric and ginger. Other knowledge about nature, namely knowing the journey of the moon and stars and trusting the existence of natural laws in every human being with the book of "Parhalaan" (astrology).

Batak people are known as music lovers. Almost all sub-tribes have a unique type of art and are different from other sub-tribes. The arts of the Toba Batak people themselves are quite diverse, ranging from dances, musical instruments, and types of singing. The dance that is the hallmark of the Toba Batak people is the tor-tor dance with various types of dance names for different activities. The Toba Batak people also have a philosophy in their lives. The philosophical system in the Toba Batak language is called Dalihan Na Tolu (Tungku Nan Tiga), which means that the Batak people have three important positions in kinship [8]. 


\section{Methodology}

In analyzing the design of this museum, several approaches can be made related to the design goals. These approaches are field studies, literature studies, comparative studies, and secondary data. The next step is the design analysis. At this stage, analysis is generated on a direct basis of field observations. The final step is the design concept. This concept was made through observing user needs, environment, analysis, and studies conducted, problems found, and the solution obtained [9].

\section{$4 \quad$ Result and Discussion}

\subsection{Project Description}

The design of the Toba Batak Art and Culture Museum is on Sisingamaraja Street, Medan Kota District, Medan City, North Sumatra Province, Indonesia. The location of this design is a business district, sports stadium, and historic area. The existing condition at the design location currently stands a shopping centre building with leased land from the Medan city government with a flat land contour condition and is surrounded by densely populated buildings. The measurement of the area at the project site was carried out using Google Earth so that the total amount of the entire design of the existence of the design site was found to be a supporting factor for the success of a museum building area of $5706.52 \mathrm{~m}^{2}$. The site that has been determined is a little square-shaped with an orientation towards the Sisingamaraja road (Figure $1)$.

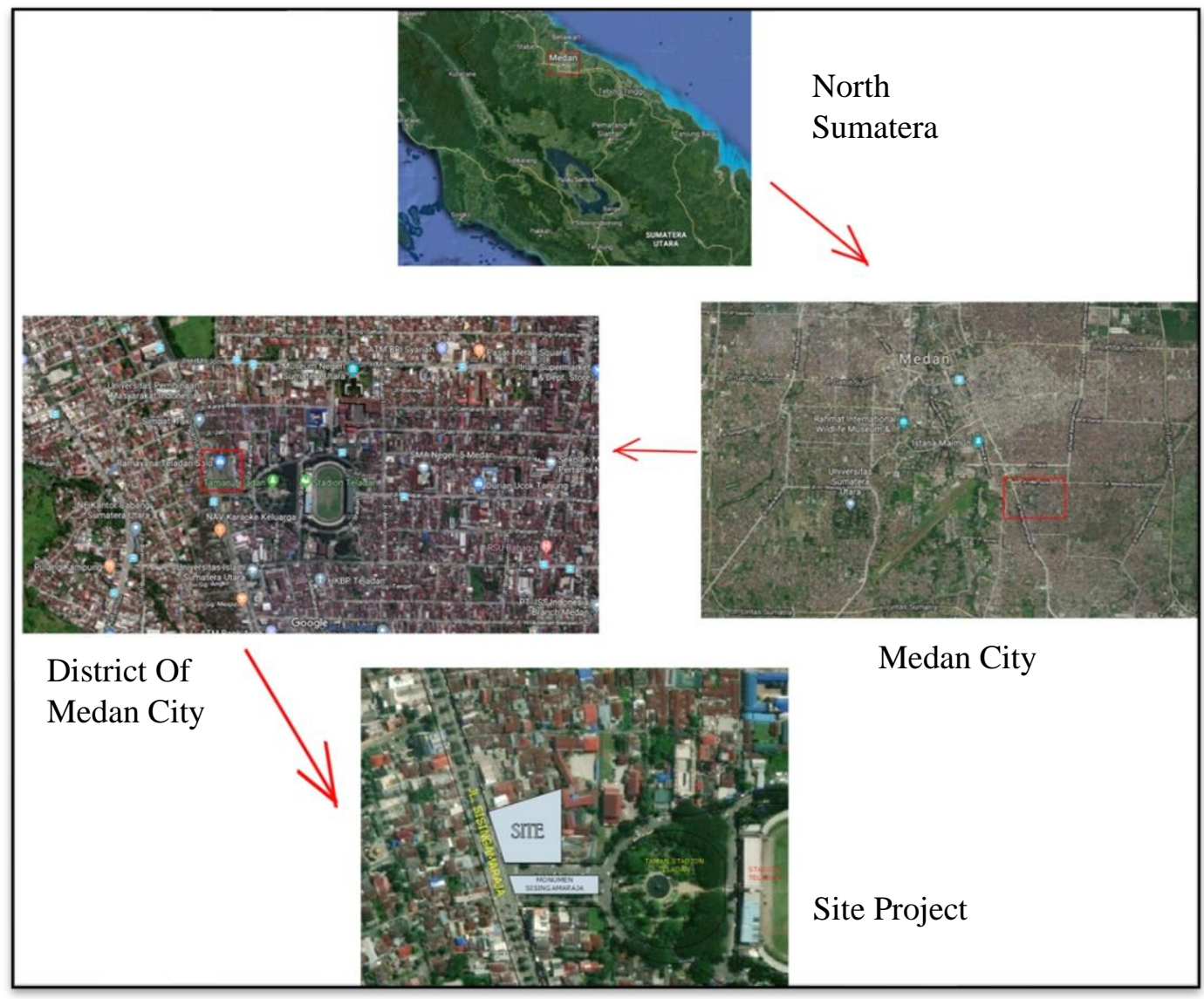

Figure 1 Map of the Project Site 


\subsection{Regional Boundaries}

The macro design area located in the Medan Kota sub-district is very close to the city centre and is surrounded by several sub-districts in the city of Medan. The boundaries of the Medan Kota sub-district Area (a) Northside is bordered by Medan Perjuangan sub-district area; (b) The East is bordered by Medan Area and Medan Deli sub-district area; (c) Southside is bordered by Medan Amplas sub-district area; (d) Westside is bordered by Medan Maimun sub-district area [10].

\subsection{Basic Concept}

The concept applied to the museum building is very closely related to the Toba Batak culture. To achieve the Neo Vernacular architectural theme, the design principles will be used as much as possible inside and outside the building [11].

The Concept of Applying the Mass General Form. The tradition of receiving guests warmly in the Culture of the Batak people is ingrained. Families warmly receive guests and are drawn to the yard. They were pulling the yard into a decisive setback into the building lobby. This principle is applied in the form of museum masses by opening a vast space/lobby so that visitors and the surrounding community are interested in entering or visiting the museum. Orient the building of the Sisingamaraja monument as a sign of honour and appreciate the existing monument to take the meaning/symbol of the Batak and put it in the museum's concept. The ornament on ulos cloth is very well known worldwide, originating from the Toba Batak culture. The uniqueness of the ulos cloth ornament can be used for wall ornamentation and other building materials to strengthen the Toba Batak culture concept in the design of this museum.

The Concept of Applying Themes to Buildings: a) The use of wood/rattan material used by the ancient Toba Batak community to tie the oblique wall of the Ruma Bolon was applied to the walls of the museum using more modern material technology; b)Utilization of the Bolon traditional house system to apply interpretations in the form of mass and museum facades, such as houses on stilts and roof forms; c)Applying the concept of dominant open space with modern elements outside the building.

Basic Concept of Toba Batak Museum Principles. The principle of the Toba Batak museum is to combine all the customs of the Batak Toba tribe and its arts and introduce them to everyone by using the principles of Education and Entertainment [12]. All people who visit this museum will be presented with the existence of teaching and learning activities about the routine of the Toba Batak tribe and tell all the traditions and Culture of the Toba Batak.

\subsection{Outdoor/Tread Design Concept}

The outdoor space zone is divided into the building mass, amphitheatre \& outdoor space, parking zone, GSB, and the main lobby museum. The shape of the building mass is inspired by 
the shape of the site, which is dominantly a rectangular straight line. With the vast-open space, this museum can create an impression that is friendly to the surrounding environment. Right in front of the site, the Sisingamaraja Monument stands tall to interconnect with the museum's concept (Figure 2).

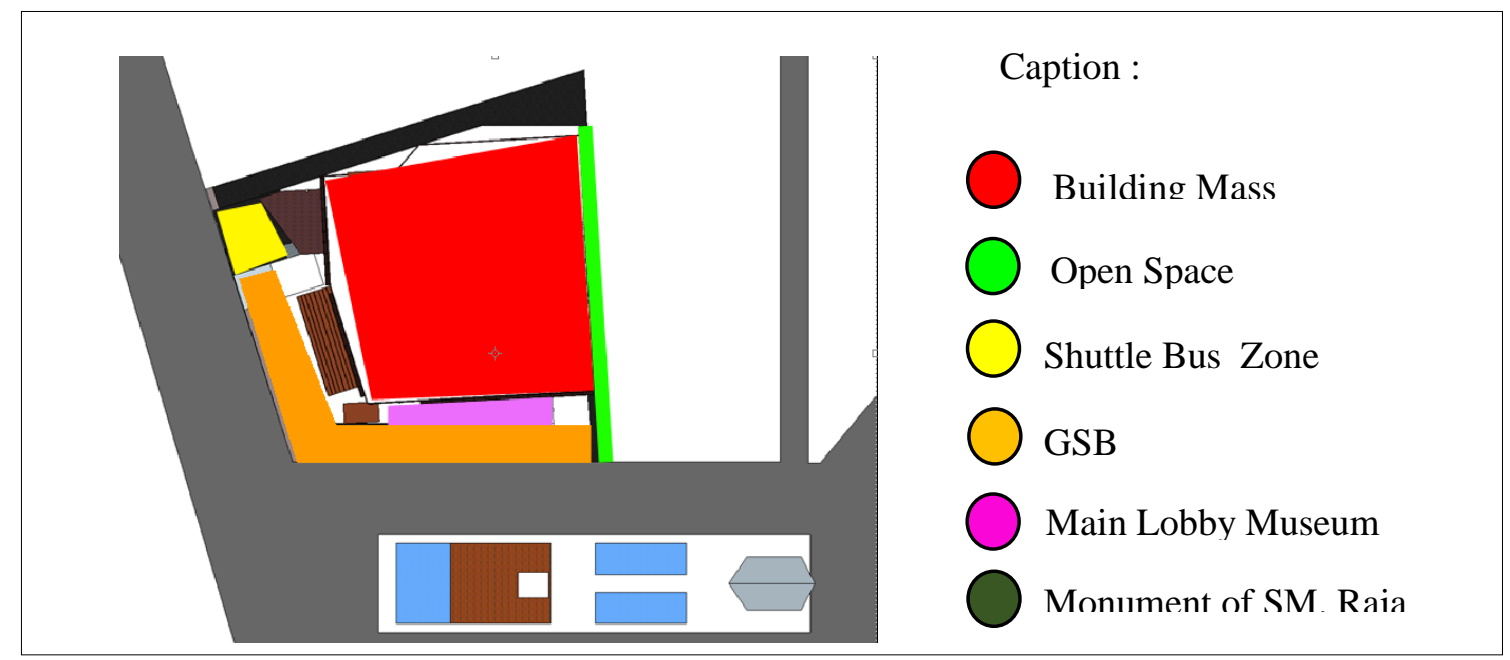

Figure 2 Zoning Concepts of Exterior Space

The outdoor space in the museum design uses several types of plants and pedestrian/vehicle pavement materials to improve the quality of green open spaces, comfortable and safe for museum users (Figure 3) [13].

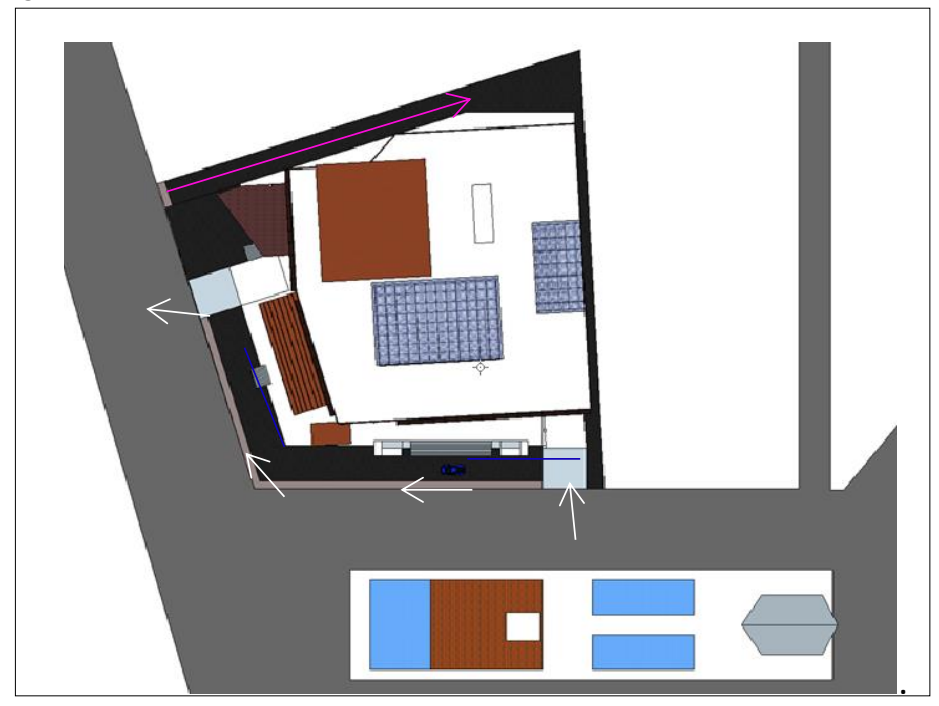

Figure 3 Concept of Circulation

The following is an explanation of Figure 3 which describes the pedestrians around the museum. There are several points in the following table namely, circulation of cars and motorbikes, pedestrian circulation, and transporting truck \& bus circulation (Tabel 1). 
Tabel 1 Description Of Figure 3

\begin{tabular}{|c|c|}
\hline$\square$ & $\begin{array}{l}\text { Circulation of cars and motorbikes. } \\
\text { Vehicles can only enter the basement if you want to go to the exit gate. } \\
\text { Because the pedestrian concept is applied in the outer space of the main lobby. }\end{array}$ \\
\hline & $\begin{array}{l}\text { Pedestrian Circulation. } \\
\text { Parking - Main Lobby - Museum - Park - Amphitheatre } \\
\text { Parking - Ampitheater - Park - Museum - Main Lobby }\end{array}$ \\
\hline$\square$ & $\begin{array}{l}\text { Transporting Truck \& Bus Circulation } \\
\text { Can only enter \& exit the right side of the site. }\end{array}$ \\
\hline
\end{tabular}

(a) Vehicle access, the pavement used is made from paving blocks, so that maximum rainwater absorption in the parking area; (b) Main Lobby \& Outdoor, the primary material used in this section is the arrangement of rock paving and grass block that is resistant to any weather; (c) Green open space park, using mini elephant grass with maximum greening; (d) Garden trees, using Drasena Drako trees and evergreen shrimp trees. Apart from being an ornamental plant, this plant also neutralizes the air around the tree, so it remains cool even in hot weather condition (Figure 4).

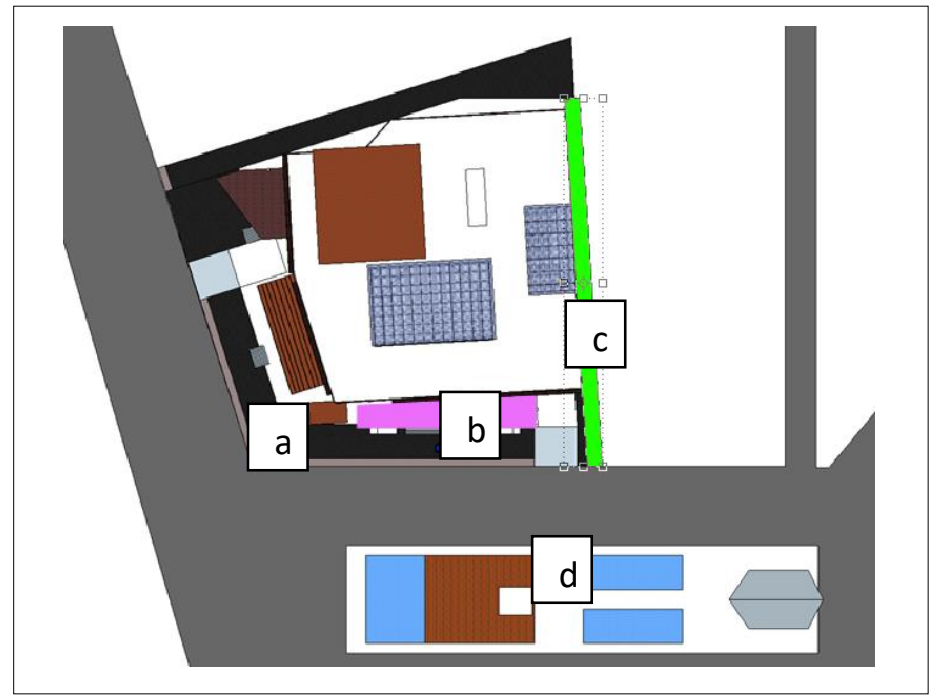

Figure 4 Concept of Vegetation

By raising the impression of openness, the design of the museum's lobby is designed specifically for pedestrians and open areas. The front facade of the museum is not disturbed by unfavourable views. Then the concept of cultural interpretation of Toba Batak culture is achieved, namely the impression of a warm welcome to visitors who come (Figure 5). 


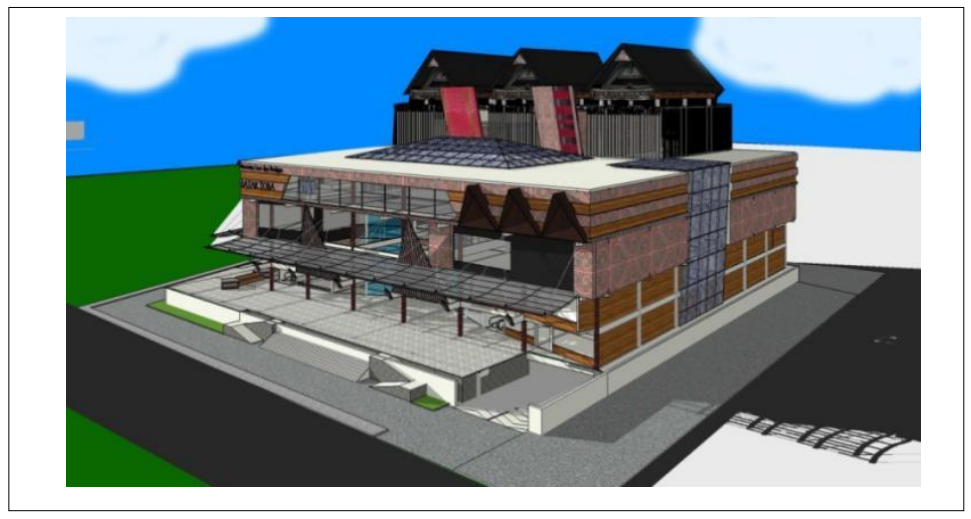

Figure 5 Concept of View

\subsection{Interior Design Concept}

The Museum Interior zoning zone is divided into four sections, as follows: (a) Public, is a zone that is directly related to visitors. In this part of the public zone, there are rooms directly related to museum visitors, namely the lobby, entrance, atrium, reception, cafe, waiting room; (b) Semipublic, which is a transition between the manager zone and visitors. In this part of the semipublic zone, there is a prayer room, medical centre, parking area, photo booth, souvenir shop, library and education room; (c) Private, is a zone that is used for the benefit of managers. The rooms in this private zone section are the Administration Room, Leadership Room, Meeting Room, and Security Post; (d) Service is a zone that is closely related to service activities. This Service Zone has rooms, namely Staff Room, Utility Room, R. Equipment \& Storage and Loading Dock [14].

(a) The Mass composition is influenced by the shape of the site, which is a dominantly straight line and has four angles; (b) With the space available for museum activities, namely the shuttle bus, the masses form an angle provided for the shuttle bus space, is oriented towards the Sisingamaraja road; (c) According to the primary orientation towards the Sisingamaraja monument, which is right on the side of the site, the form of the mass is more focused on the monument's orientation; (d) The composition of the mass on the 5th floor is influenced by the attraction of space contained in the museum space associated with the belief 'Banua Ginjang' to form a prominent mass (Figure 6) [15]. 


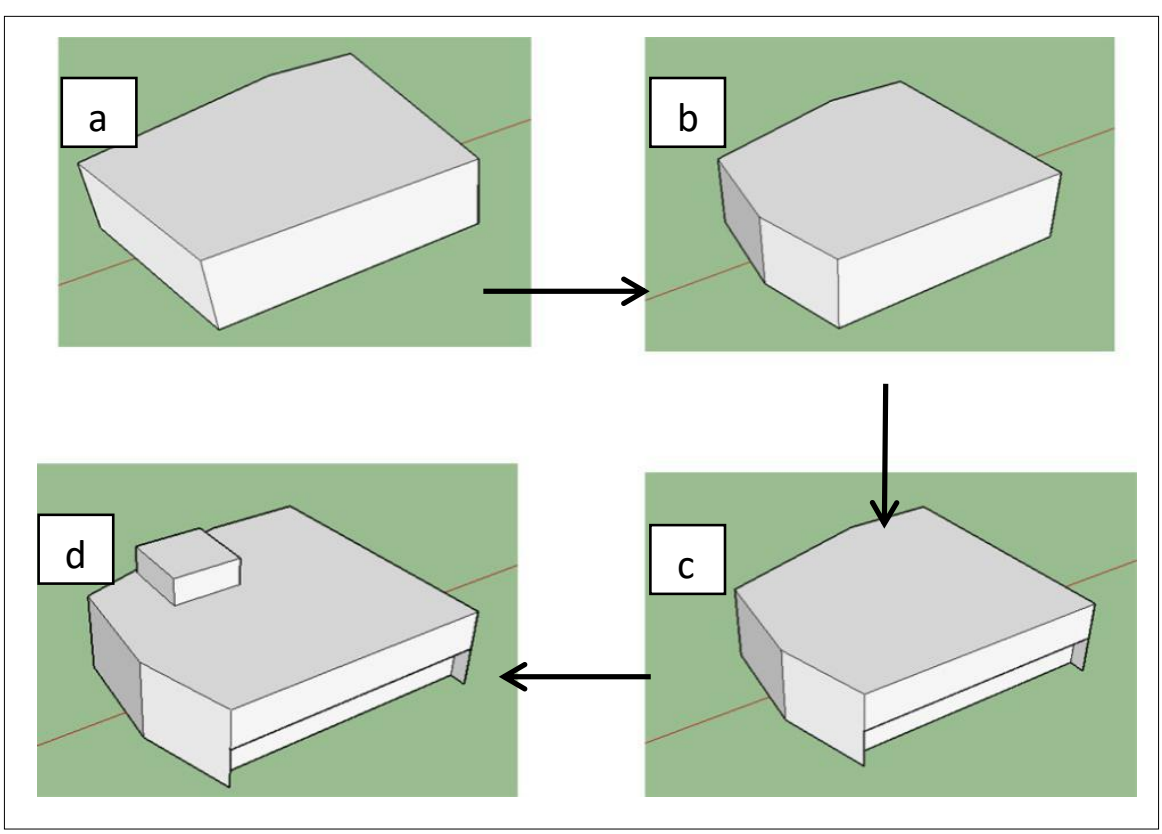

Figure 6 Concept of Mass and Changeable

The following is a picture of the exterior and interior from several points of view of the museum building, which shows the application of the Batak Toba theme to the forms of the Museum building (Figure 7).

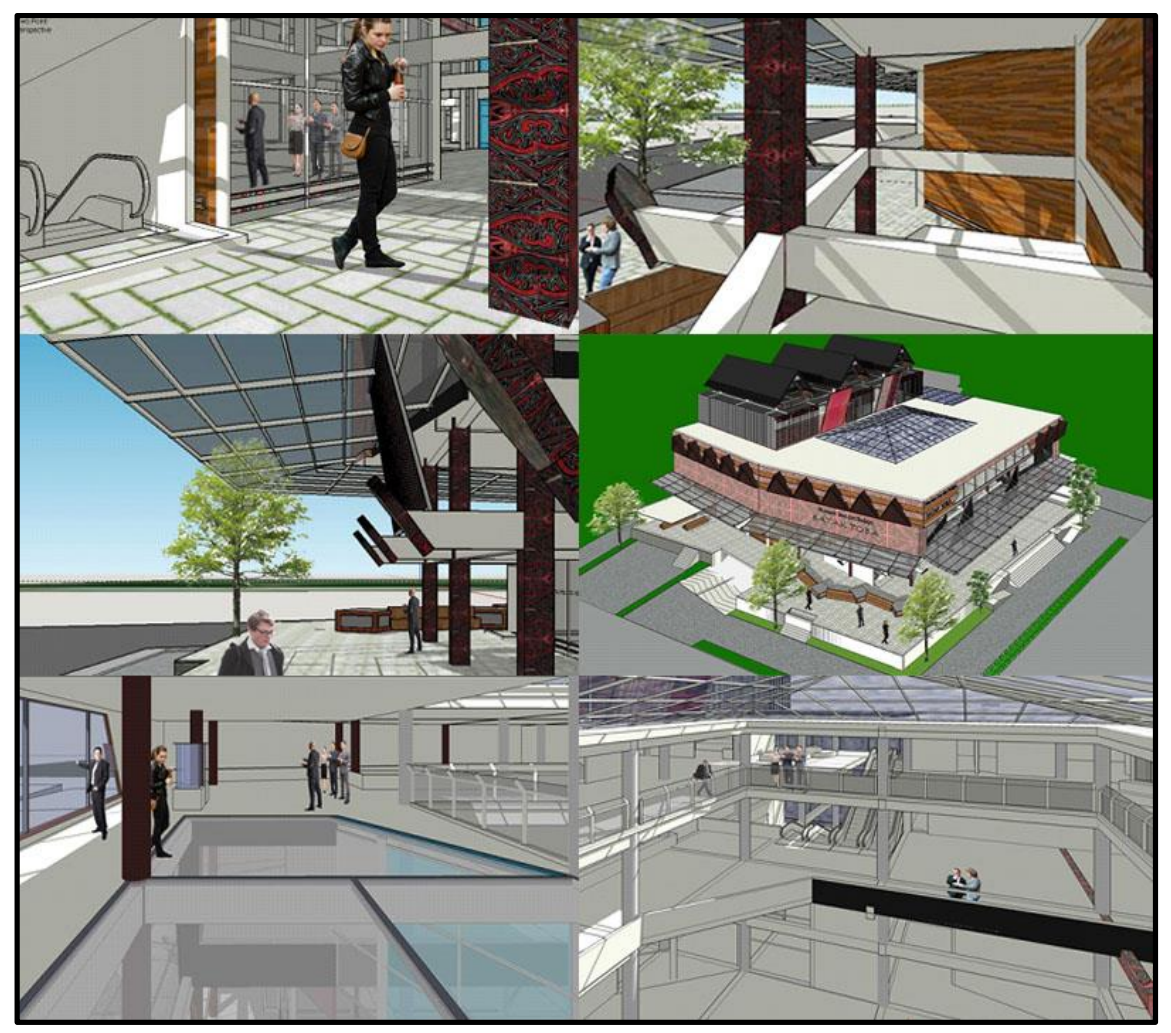

Figure 7 Building Exterior and Interior

\section{Conclusion}

The design of the Toba Batak Art and Culture Museum is located in Medan Kota Sub-district, Medan City; aside from being a recreational tourism facility for visitors, it also functions as a forum to preserve the arts and Culture of the Toba Batak tribe by giving the Edutainment 
concept to museum visitors. In a modern way, the museum is located in the centre of Medan, presents the authentic atmosphere of the Toba Batak village inside and outside the museum by applying stilt houses and Gorga Batak ornaments on almost all sides of the building. The central concept of this design is to connect the points of tourist areas around the location, such as the Great Mosque, Maimun Palace, Tirtanadi Water Tower and Merdeka Walk, thus creating a path that has the potential to improve the quality of the theme of the Medan city environment by making Shuttle Bus tourism activities. The maximum water and outdoor attractions are also a concept prioritized by the building of this museum, taking into account the regulations of the Medan city government.

This museum applies the Neo Vernacular architectural theme by adapting buildings to the city environment of Medan. So that in addition to Batak or non-Batak visitors can be one of the many influences to preserve Toba Batak arts and Culture. By applying the concept of NeoVernacular architecture to the museum, it is expected to have a positive impact on the environment of Medan, its buildings and its users.

\section{Acknowledgement}

This research is about designing a museum of Batak Toba Art and Culture with the concept of education and entertainment and it is aimed at tourism managers in Medan. Authors thanks to the Department of Architecture, the University of North Sumatra, for the guidance given to the author in the process of writing this research.

\section{REFERENCES}

[1] Kuntowijoyo, Pengantar Ilmu Sejarah, Yogyakarta: Tiara Wacana, 2001.

[2] N. Bilkis, Sejarah Kota Medan, Medan, 2014.

[3] P. Indonesia, "Peraturan Pemerintah Tentang Museum," in Pemerintah Indonesia (PP), Indonesia, 2015.

[4] W. Contributors, "Wiki," 2019. [Online]. Available: http://id.wikipedia.org/wiki/Museum/. [Accessed 1210 2019].

[5] T. A. Ahmad, "Strategi Pemanfaatan Museum Sebagai Media Pembelajaran Pada Materi Zaman Prasejarah," Paramita Hist. Stud. J., pp. vol. 20, no. 1, 2011.

[6] A. J. Adinda, "Apa itu Seni (dan Filsafat Seni)," 244 2016. [Online]. Available: http://rembugbudoyo.wordpress.com/2016/04/24/apa-itu-seni-dan-filsafat-seni-bag-2/. [Accessed 1110 2019].

[7] W. Contributors, "Budaya," $2019 . \quad$ [Online]. Available: http://id.wikipedia.org/wiki/Budaya/. [Accessed 1210 2019].

[8] Unknown, "Sejarah Suku Batak Toba," 3 2016. [Online]. Available: http://becakbalige.blogspot.com/2016/03/sejarah-suku-batak-toba.html/. [Accessed 1210 2019]. 
[9] H. Wijaya, "Metode-Metode Penelitian Dalam Penulisan Jurnal Ilmiah Elektronik," OSF Prepr., pp. 21-22, 2019.

[10] P. K. Medan, "Profil Kecamatan Medan Kota," 2014. [Online]. Available: http://pemkomedan.go.id/hal-medan-kota-.html/. [Accessed 1210 2019].

[11] C. Jencks, Language of Post-Modern Architecture, 1990.

[12] A. Sohilin, "Metode Edutainment Dalam Pembelajaran Menyenangkan," 4 2015. [Online]. Available: $\quad$ http://visiuniversal.blogspot.com/2015/04/metode-edutainment-dalampembelajaran.html?m=1/. [Accessed 1310 2019].

[13] B. Hansen, Great Exhibits!: An Exhibits Planning and Construction Handbook for Small Museums, Maryland: Rowman \& Littlefield, 2017.

[14] A. A. Wulandri, "Dasar-Dasar Perancangan Interior Museum," Humaniora, pp. 246-257, 2014.

[15] F. D. K. Ching, Arsitektur, Bentuk, dan Susunannya, 2000. 